\title{
Effect of Poor Diabetic Control and Obesity on Whole Body Protein Metabolism in Man
}

\author{
K.S. Nair, J.S. Garrow, C. Ford, R. F. Mahler and D. Halliday \\ Division of Clinical Sciences, Clinical Research Centre and Northwick Park Hospital, Harrow, Middlesex, UK
}

\begin{abstract}
Summary. We have investigated whole body protein turnover in the fasted state in five normal men, five male Type 1 diabetic patients off insulin therapy, and five obese women, using IV ${ }^{13} \mathrm{C}$-leucine as a tracer. In diabetic patients, there was, as expected, a greater net loss of protein in the fasted state than in normal subjects. However, contrary to animal and studies in vitro, our diabetic patients in the fasted state showed a greater rate of protein synthesis than normal subjects $(p<0.01)$. The increased net loss of protein in diabetic patients compared with normal subjects arose because, in the diabetic patients, protein breakdown was increased even more than protein synthesis under the conditions of this study. Plasma leucine con-
\end{abstract}

centration was higher in diabetic and in insulin-insensitive obese patients than in normal subjects $(p<0.01)$, and higher in diabetic than in obese patients $(p<0.05)$. The rate of protein synthesis per $\mathrm{kg}$ lean body mass was also higher in diabetic patients than in obese or normal subjects $(p<0.01)$, and higher in obese than in normal subjects $(p<0.05)$. We conclude that, in human subjects, whole body leucine and protein metabolism are very sensitive to the action of insulin.

Key words: Protein turnover, protein synthesis, diabetes, obesity, insulin action.
An association between diabetes mellitus and deranged protein metabolism has been known for many centuries. The Sanscrit literature of $600 \mathrm{BC}$ referred to the emaciation in 'honey urine disease' [1] and the ancient Greek literature referred to 'melting down of flesh' in the urine of diabetic patients [2].

Our knowledge about the effects of insulin on protein turnover in the intact animal [3, 4] or in man [5-7] has been obtained primarily from nitrogen balance studies. In dogs with experimentally induced diabetes and in diabetic patients after withdrawal of insulin therapy $[5,8]$, there is an increased urinary nitrogen loss, but this can be reversed by insulin therapy. These nitrogen balance studies do not distinguish between changes in the rates of protein synthesis and degradation.

Elevated plasma amino acids in diabetic patients fall following insulin therapy $[9,10]$. Insulin also inhibits the release of amino acids from tissues of the human forearm [11]. Animal studies in vivo and studies in vitro show that insulin inhibits muscle protein breakdown and enhances protein synthesis [12-15].

From this evidence, it appears that insulin deficiency results in a reduced protein synthesis rate and enhanced net protein breakdown. Results from animal work do not necessarily apply to man, since in experi- mental animals, islet cell function is completely abolished and the effects of diabetogenic agents such as alloxan and streptozotocin on tissues other than pancreatic islets are uncertain. Hence, we designed the following experiment on whole body protein turnover in Type 1 (insulin-dependent) diabetic patients, insulinresistant obese subjects and lean, normal subjects. ${ }^{13} \mathrm{C}$ labelled leucine was used as a tracer to study protein turnover. Since it is an essential amino acid, the only source of leucine in the fasted state is body protein and hence changes in leucine turnover should reflect those of whole body protein.

\section{Materials and Methods}

\section{Subjects}

The protocol was approved by the Northwick Park Hospital Ethical Committee. The Type 1 diabetic patients were volunteers from the outpatient clinic. The diabetic patients and healthy lean volunteers had weight $/$ height ${ }^{2}$ less than $25 \mathrm{~kg} / \mathrm{m}^{2}$ whereas, the obese women had above $35 \mathrm{~kg} / \mathrm{m}^{2}$. None of the subjects had any known cardiovascular or renal complications (Table 1). All subjects gave their informed consent. 
Table 1. Details of the subjects studied

\begin{tabular}{|c|c|c|c|c|c|}
\hline Subjects & $\begin{array}{l}\text { Age } \\
\text { (years) }\end{array}$ & $\begin{array}{l}\text { Sex } \\
\text { ratio } \\
M / F\end{array}$ & $\begin{array}{l}\text { Weight } \\
\text { (kg) }\end{array}$ & $\begin{array}{l}\text { Weight/ } \\
\text { height } \\
\left(\mathrm{kg} / \mathrm{m}^{2}\right)\end{array}$ & $\begin{array}{l}\text { Lean body } \\
\text { mass } \\
(\mathrm{kg})\end{array}$ \\
\hline $\begin{array}{l}\text { Diabetic } \\
\text { patients }\end{array}$ & $28.2 \pm 10.5$ & $5 / 0$ & $73.8 \pm 8.2$ & $22.8 \pm 1.6$ & $60.0 \pm 8.3$ \\
\hline $\begin{array}{l}\text { Obese } \\
\text { subjects }\end{array}$ & $25.6 \pm 2.9$ & $0 / 5$ & $117.8 \pm 8.2$ & $45.3 \pm 3.8$ & $55.4 \pm 5.0$ \\
\hline $\begin{array}{l}\text { Lean } \\
\text { subjects }\end{array}$ & $36.2 \pm 11.75$ & $5 / 0$ & $70.8 \pm 7.3$ & $22.9 \pm 1.15$ & $59.1 \pm 12.1$ \\
\hline
\end{tabular}

Results expressed as mean \pm SD

Table 2. Fasting plasma levels of leucine, glucose, insulin and C-peptide in three groups of subjects during a primed-continuous infusion of $\mathrm{L}-\left[1-{ }^{13} \mathrm{C}\right]$ leucine

\begin{tabular}{lllll}
\hline Subjects & $\begin{array}{l}\text { Plasma } \\
\text { leucine } \\
(\mu \mathrm{mol} / \mathrm{l})\end{array}$ & $\begin{array}{l}\text { Plasma } \\
\text { glucose } \\
(\mathrm{mmol} / 1)\end{array}$ & $\begin{array}{l}\text { Plasma } \\
\text { insulin } \\
(\mathrm{pmol} / \mathrm{l})\end{array}$ & $\begin{array}{l}\text { Plasma } \\
\text { C-peptide } \\
(\mathrm{pmol} / 1)\end{array}$ \\
\hline $\begin{array}{c}\text { Diabetic } \\
\text { patients } \\
(n=5)\end{array}$ & $229 \pm 48^{\mathrm{a}, \mathrm{b}}$ & $20.12 \pm 4.2^{\mathrm{a}, \mathrm{b}}$ & $\begin{array}{l}\text { Not } \\
\text { measured }\end{array}$ & $145 \pm 152$ \\
$\begin{array}{c}\text { Obese } \\
\text { subjects } \\
(n=5)\end{array}$ & $162 \pm 26^{\mathrm{a}}$ & $4.5 \pm 0.7$ & $288 \pm 184^{\mathrm{c}}$ & $\begin{array}{l}\text { Not } \\
\text { measured }\end{array}$ \\
$\begin{array}{c}\text { Lean } \\
\text { subjects } \\
(n=5)\end{array}$ & $116 \pm 7$ & $4.78 \pm 0.3$ & $80 \pm 60$ & $\begin{array}{l}\text { Not } \\
\text { measured }\end{array}$ \\
\hline
\end{tabular}

Results are expressed as mean \pm SD. Upper limit of normal: plasma glucose $6 \mathrm{mmol} / 1$, plasma insulin $151 \mathrm{pmol} / 1$. $^{\text {a }}>$ lean controls $(p<0.01) ;{ }^{\mathrm{b}}>$ obese subjects $(p<0.05) ; \quad \mathrm{c}>$ lean controls $(p<$ 0.05 ). Normal range for plasma C-peptide $307-920 \mathrm{pmol} / 1$

\section{Materials Used}

$\mathrm{L}-\left[1{ }^{13} \mathrm{C}\right]$ leucine $\left(92 \%{ }^{13} \mathrm{C}\right)$ and sodium $\left({ }^{13} \mathrm{C}\right)$ bicarbonate $\left(90 \%{ }^{13} \mathrm{C}\right)$ were obtained from KOR Isotopes, Cambridge, Massachussets, USA.

\section{Protocol}

Diabetic patients were admitted to the metabolic ward $72 \mathrm{~h}$ before the study and their insulin treatment was changed to neutral soluble insulin given every $6 \mathrm{~h}$. The last dose of insulin on the day before the study was omitted.

All subjects were on a weight-maintaining diet for at least $72 \mathrm{~h}$ before the study, but fasted for $12 \mathrm{~h}$ overnight before and during the period of infusion. Each infusion commenced between 0800 and $0900 \mathrm{~h}$. Blood samples were collected from an antecubital vein cannula kept patent with heparinised, normal saline. Through a contralateral catheter, a priming dose of the $\mathrm{NaH}^{13} \mathrm{CO}_{3}(0.1 \mathrm{mg} / \mathrm{kg}$ lean body mass $)$ and $\mathrm{L}-\left[1-{ }^{13} \mathrm{C}\right]$ leucine $(0.65 \mathrm{mg} / \mathrm{kg}$ lean body mass $)$ was administered, followed immediately by a constant IV infusion of $\mathrm{L}-\left[1-{ }^{13} \mathrm{C}\right]$ leucine $\left(0.5-0.8 \mathrm{mg} \cdot \mathrm{kg}\right.$ lean body mass $\left.{ }^{-1} \cdot \mathrm{h}^{-1}\right)$.

If the leucine had been given as an unprimed infusion it would have taken about $10-12 \mathrm{~h}$ to reach ${ }^{13} \mathrm{C}$ equilibrium in the leucine and bicarbonate pools. With a priming dose, equilibrium is reached in about $90 \mathrm{~min}$. This increases the acceptability of the protocol to the patient, saves expense of leucine, and reduces the chance of recycling of leucine back from the tissues into the metabolic pool.

Three expired air samples and one blood sample were collected just before the administration of isotope and then at $15 \mathrm{~min}$ intervals from $90 \mathrm{~min}$ after the start of the infusion to the end of the study. Blood samples for leucine, insulin and C-peptide were collected in heparinised tubes and for glucose in fluoride/oxalate tubes. All sam- ples were kept on ice and were centrifuged at $4^{\circ} \mathrm{C}$ within $1 \mathrm{~h}$ of collection.

The total $\mathrm{CO}_{2}$ production and respiratory quotient were recorded continuously at $10 \mathrm{~min}$ intervals from $90 \mathrm{~min}$ till the end of the study by indirect calorimetry [16].

Amino acids were isolated from plasma using a rapid cation-exchange resin procedure [17]. Following derivatisation as the $\mathrm{N}, \mathrm{N}, \mathrm{O}$ heptafluorobutyryl isobutyl esters separation of leucine was achieved on a $25 \mathrm{~m} \times 0.25 \mathrm{~mm}$ internal diameter ' $\mathrm{CP}$ Sil 5 ' fused silica capillary column (Chrompack (UK), London, UK) and its ${ }^{13} \mathrm{C} /{ }^{12} \mathrm{C}$ ratio determined in a quadrupole mass spectrometer (Finnigan 4000, Finnigan MAT, Hemel Hempstead, UK). We have used negative ion chemical ionisation conditions with methane as reactant gas and monitored ions $\mathrm{m} / \mathrm{z}$ (mass/charge) 364 and 363 respectively which correspond to the molecular ion having lost a hydrogen fluoride fragment from each compound. Quantitation of leucine was achieved using nor-leucine as internal standard. The leucine/nor-leucine ratio obtained was compared with a calibration curve (prepared by adding known amounts of leucine to control plasma) to obtain the concentration.

Expired $\mathrm{CO}_{2}$ was initially collected in 2-1 polythene bags and an aliquot was immediately transferred to an evacuated glass sample bottle. ${ }^{13} \mathrm{CO}_{2}$ enrichment was mcasured in an isotopc-ratio mass spectrometer (VG 602D, VG Isogas, Cheshire, UK) following the cryogenic extraction of the $\mathrm{CO}_{2}$ and the enrichment was corrected for oxygen isotopes [18].

The accuracy of these measurements was checked in the following manner. The rate of $\mathrm{CO}_{2}$ production by an alcohol lamp was measured by indirect calorimetry, and this estimate was compared with that based on the weight of alcohol burned. The mean difference between the two estimates was $<2 \%$. Replicate measurements of the ${ }^{13} \mathrm{C}$ enrichment of a standard sample of leucine showed an SD of $<1 \%$, and replicate measurements of leucine concentration an $\mathrm{SD}<4 \%$. Replicate measurements of ${ }^{13} \mathrm{CO}_{2}$ atom percent excess had an SD of $<1 \%$.

Total body potassium values (from ${ }^{40} \mathrm{~K}$ ), for calculation of lean body mass, were obtained using a whole body counter [19].

Plasma insulin was assayed using an Amersham kit (Amersham International, Amersham, UK), and plasma C-peptide was assayed using specific antiserum (Guildhay antiserum, Department of Biochemistry, Guildford University, Surrey, UK) employing a doubleantibody technique [20].

Leucine metabolism was calculated using the standard two-pool stochastic model [21] where leucine flux $\left(\mathrm{Q}_{\mathrm{L}}\right)$ is given by the formula: $\mathrm{Q}_{\mathrm{L}}=\mathrm{S}+\mathrm{O}=\mathrm{B}+\mathrm{I}$

where $\mathrm{Q}_{\mathrm{L}}=$ flux (rate of leucine turnover); $\mathrm{S}=$ rate of leucine incorporation into protein; $\mathrm{O}=$ rate of leucine oxidation; $\mathrm{B}=$ rate of leucine entering the plasma pool from protein breakdown, and $\mathrm{I}=$ the rate of dietary intake and/or the rate of ${ }^{13} \mathrm{C}$ leucine infusion ( $\mu \mathrm{mol}$ $\mathrm{kg}^{-1}$ lean body mass $\cdot \mathrm{h}^{-1}$ ). Estimates of $\mathrm{Q}, \mathrm{S}$ and $\mathrm{B}$ in terms of protein were calculated on the assumption that the leucine content of mixed body protein is $8 \%$ [22] and expressed per $\mathrm{kg}$ lean body mass to correct for the gross body compositional differences in our subject and patient groups.

The model assumes that a steady state has been reached. The stability and precision of measurement at plateau of ${ }^{13} \mathrm{CO}_{2}$ labelling and $\mathrm{CO}_{2}$ production rate, and of plasma ${ }^{13} \mathrm{C}$ leucine labelling and plasma leucine concentration, was tested in two ways. First, a linear regression line was fitted to the points at plateau, lasting not less than $1.5 \mathrm{~h}$. The slope of this line was not significantly different from zero. Second, the scatter of points was expressed as a coefficient of variation about the mean value.

\section{Results}

Fasting concentrations of leucine and glucose are shown for all groups in Table 2. The concentrations of both leucine and glucose were higher in diabetic patients than in lean normal $(p<0.01)$ or obese subjects $(p<0.05)$. The leucine concentration in obese subjects, although lower than that in the diabetic patients, was 
Table 3. Test of steady-state conditions in $\mathrm{CO}_{2}$ labelling and production rate, and in plasma leucine labelling and concentration

\begin{tabular}{|c|c|c|c|c|c|c|c|c|}
\hline \multirow[t]{2}{*}{ Subjects } & \multicolumn{2}{|c|}{${ }^{13} \mathrm{CO}_{2}$ atom $\%$ excess } & \multicolumn{2}{|c|}{$\mathrm{CO}_{2}$ production } & \multicolumn{2}{|c|}{${ }^{13} \mathrm{C}$-leucine enrichment } & \multicolumn{2}{|c|}{ Leucine concentration } \\
\hline & $\mathrm{a}$ & $\mathrm{b}$ & $\mathrm{a}$ & $\mathrm{b}$ & $\bar{a}$ & $\mathrm{~b}$ & $\mathrm{a}$ & $b$ \\
\hline $\begin{array}{l}\text { Diabetic patients } \\
\quad(n=5)\end{array}$ & $1.95 \pm 0.6$ & $-0.02 \pm 0.05$ & $2.4 \pm 0.07$ & $-0.02 \pm 0.02$ & $2.7 \pm 1.0$ & $0.01 \pm 0.1$ & $3.1 \pm 1.4$ & $-0.008 \pm 0.07$ \\
\hline $\begin{array}{l}\text { Obese subjects } \\
\quad(n=5)\end{array}$ & $1.4 \pm 0.03$ & $-0.07 \pm 0.06$ & $2.2 \pm 1.7$ & $0.06 \pm 0.08$ & $2.04 \pm 0.95$ & $0.005 \pm 0.06$ & $2.2 \pm 1.2$ & $0.02 \pm 0.06$ \\
\hline $\begin{array}{l}\text { Lean subjects } \\
\quad(n=5)\end{array}$ & $2.9 \pm 1.7$ & $-0.02 \pm 0.03$ & $2.89 \pm 1.3$ & $0.006 \pm 0.04$ & $2.2 \pm 0.4$ & $0.03 \pm 0.06$ & $2.2 \pm 0.6$ & $0.04 \pm 0.04$ \\
\hline
\end{tabular}

Values are expressed as mean $\pm \mathrm{SD}$. $a$ Coefficient of variation of points at plateau about their mean value; $b$ Slope of regression line fitted to plateau points $(\%$ per $\min )$

Table 4. Whole body leucine kinetics and derived aspects of whole body turnover in fasting male diabetic patients, obese women and lean male control subjects

\begin{tabular}{|c|c|c|c|c|c|c|c|}
\hline Subjects & & $\begin{array}{l}\text { Leucine } \\
\text { flux } \\
(\mu \mathrm{mol} / \mathrm{h})\end{array}$ & $\begin{array}{l}\text { Leucine } \\
\text { incorporation } \\
\text { into protein } \\
(\mu \mathrm{mol} / \mathrm{h})\end{array}$ & $\begin{array}{l}\text { Leucine } \\
\text { oxidation } \\
(\mu \mathrm{mol} / \mathrm{h})\end{array}$ & $\begin{array}{l}\text { Absolute rate } \\
\text { of protein } \\
\text { breakdown } \\
(\mathrm{mg} / \mathrm{h})\end{array}$ & $\begin{array}{l}\text { Protein } \\
\text { synthesis } \\
\text { rate } \\
(\mathrm{mg} / \mathrm{h})\end{array}$ & $\begin{array}{l}\text { Net } \\
\text { protein } \\
\text { loss } \\
(\mathrm{mg} / \mathrm{h})\end{array}$ \\
\hline $\begin{array}{l}\text { Diabetic } \\
\text { patients } \\
(n=5)\end{array}$ & $\begin{array}{l}\text { per kg LBM } \\
\text { per kg BW }\end{array}$ & $\begin{array}{l}143.0 \pm 15^{\mathrm{a}, \mathrm{b}} \\
116.0 \pm 17^{\mathrm{a}, \mathrm{b}}\end{array}$ & $\begin{array}{r}106.5 \pm 12.6^{\mathrm{a}, \mathrm{b}} \\
86.8 \pm 13.0^{\mathrm{a}, \mathrm{b}}\end{array}$ & $\begin{array}{l}36.2 \pm 4.0^{\mathrm{a}, \mathrm{b}} \\
29.5 \pm 4.9^{\mathrm{a}, \mathrm{b}}\end{array}$ & $\begin{array}{l}241.9 \pm 26.1^{\mathrm{a}, \mathrm{b}} \\
197.9 \pm 28.8^{\mathrm{a}, \mathrm{b}}\end{array}$ & $\begin{array}{l}180.5 \pm 21.3^{\mathrm{a}, \mathrm{b}} \\
147.7 \pm 21.9^{\mathrm{a}, \mathrm{b}}\end{array}$ & $\begin{array}{l}61.3 \pm 6.8^{\mathrm{a}, \mathrm{b}} \\
50.0 \pm 8.3^{\mathrm{a}, \mathrm{b}}\end{array}$ \\
\hline $\begin{array}{l}\text { Lean } \\
\quad \text { subjects } \\
(n=5)\end{array}$ & $\begin{array}{l}\text { per } \mathrm{kg} \mathrm{LBM} \\
\text { per } \mathrm{kg} \mathrm{BW}\end{array}$ & $\begin{array}{r}103.0 \pm 8 \\
85.2 \pm 9\end{array}$ & $\begin{array}{l}85.5 \pm 7.3 \\
70.1 \pm 9.3\end{array}$ & $\begin{array}{l}18.7 \pm 4.8 \\
15.2 \pm 2.7\end{array}$ & $\begin{array}{l}174.4 \pm 14.1 \\
144.4 \pm 15.6\end{array}$ & $\begin{array}{l}144.9 \pm 12.4 \\
118.9 \pm 15.8\end{array}$ & $\begin{array}{l}31.7 \pm 8.1 \\
25.7 \pm 4.6\end{array}$ \\
\hline
\end{tabular}

Results are expressed as mean \pm SD. LBW: lean body weight; BW: body weight. Plateau values were obtained between $2-4 \mathrm{~h}$ of infusion. Leucine flux is derived from mean plasma ${ }^{13} \mathrm{C}$-leucine labelling. Leucine oxidation is derived from mean ${ }^{13} \mathrm{CO}_{2}$ labelling. Leucine incorporation is (flux oxidation). Protein turnover values are calculated on the assumption that $8 \%$ of mixed body protein is leucine [22].

Significance of differences: a higher than lean subjects $p<0.01 ; \quad{ }^{\mathrm{b}}$ higher than obese subjects $p<0.01$; ${ }^{\mathrm{c}}$ higher than lean subjects $p<$ $0.05 ;{ }^{\mathrm{d}}$ lower than lean subjects $p<0.01$

significantly higher than in lean normal subjects $(p<$ $0.01)$. Fasting plasma glucose concentration was not significantly different between obese and lean normal subjects, but the obese subjects had significantly higher insulin concentrations $(p<0.05)$. It is not possible to make a valid assay of plasma insulin concentration in the diabetic patients, but their plasma C-peptide concentration was below the normal range.

The objective of the primed continuous infusion of ${ }^{13} \mathrm{C}$ leucine was to establish a steady state in which the mathematical model was valid. Ideally, the rate of isotopic labelling in expired $\mathrm{CO}_{2}$ and in plasma leucine should reach an absolutely constant plateau, indicating that the infused isotope has attained dynamic equilibrium with the leucine pool in the body. The data relating to the constancy and precision of plateau values for $\mathrm{CO}_{2}$ and leucine are set out in Table 3. In each case, the slope of the regression line fitted to at least five values, taken over at least $1.5 \mathrm{~h}$, was not significantly different from zero. The coefficient of variation of these values about their mean in each case was $<4 \%$.

The derived values for whole body leucine kinetics and protein turnover are given in Table 4 . By both methods, the flux, incorporation and oxidation in diabetic patients was significantly greater than in normal sub- jects $(p<0.01)$. When diabetic and normal subjects were compared on the basis of lean body mass, the diabetic patients showed a $39 \%$ higher rate of protein breakdown, a 25\% higher rate of protein synthesis, and a $97 \%$ higher net rate of protein loss. When compared on the basis of lean body mass, the obese subjects occupied a position between the diabetic and normal subjects.

\section{Discussion}

Our results confirm and quantify increased net protein breakdown in poorly controlled fasting insulin-dependent diabetic patients. In view of the unopposed action of catabolic hormones and increase in gluconeogenesis [23], we expected an increase in absolute protein breakdown and leucine oxidation in poorly controlled diabetic patients compared with lean normal subjects.

Unexpectedly, we found an elevated protein synthesis rate in poorly controlled diabetic patients. Based on available information in animal studies [13-15] and studies in vitro [12], we expected that insulin deficiency would decrease amino-acid incorporation into protein. Most animal studies [13-15] and studies in vitro conclude that muscle protein synthesis rate is reduced in diabetes; however, there is still uncertainty about the ef- 
fect of diabetes on protein synthesis in liver or gut [15, 24]. It appears that liver protein synthesis is less influenced than muscle by insulin deficiency. It may be that the increased protein synthesis is a compensatory response by the body to conserve protein stores in the presence of an obligatory increase in protein breakdown. We propose that this compensatory increase in protein synthesis in diabetes occurs in liver, gut, or other viscera. Recently, it has been suggested that leucine has an important anabolic effect on protein metabolism in muscle tissues and in man in vivo [26, 27]. It is possible, therefore, that in an insulin-deficient state, a high plasma leucine level may be responsible for an increased protein synthesis rate. Being an energy requiring reaction, an increased protein synthesis rate should therefore result in an increased energy expenditure. Our observation of an increased energy expenditure in poorly controlled diabetes [28] lends support to this proposal.

Our obese subjects with high fasting plasma insulin levels were euglycaemic, but had a higher leucine level than normal subjects. Since leucine stimulates insulin secretion [29], it is possible that in these insulin resistant obese subjects, the higher level of leucine is needed to maintain sufficient insulin secretion to achieve euglycaemia.

We conclude from our study that poor diabetic control in fasting man results not only in an increased protein breakdown but also an increased synthesis rate. Protein breakdown exceeds synthesis, resulting in a net loss of the body protein store. However, it is known that fasting causes reduced protein synthesis in normal man, so the difference between normal and diabetic man may be less obvious in the fed state [30].

Acknowledgements. We gratefully acknowledge technical assistance from Miss S. Heels and Mr. A. Percy, help from the nursing staff in Haldane and Cavendish Wards, Mr. R. Hesp of Division of Radioisotopes for measuring total body potassium, and Mrs. S. Hampton, Guildford University, for helping us to set up the C-peptide assay.

\section{References}

1. Frank LL (1957) Diabetes mellitus in the text book of Old Hindu medicine. Am J Gastroenterol 27: 76-95

2. Reed JA (1954) Aretaeus, the Cappadocian. Diabetes 3: 419-421

3. Sokhey SS, Allen FN (1924) The relationship of phosphates to carbohydrates metabolism. I. Time relationship of the changes in phosphate excretion caused by insulin and sugar. Biochem $\mathbf{J} 18$ : 1170-1184

4. Adibi SA, Madesto TA, Morse EL, Amin PM (1973) Amino acid levels in plasma, liver and skeletal muscle during protein deprivation. Am J Physiol 225: 408-414

5. Atchley DW, Loeb RF, Richards DW et al (1933) On diabetic acidosis: A detailed study of electrolyte balance following the withdrawal and reestablishment of insulin therapy. $J$ Clin Invest 12: 297-326

6. Felig P, Wahren J, Sherwin R, Palaiologos G (1977) Amino acid and protein metabolism in diabetes mellitus. Arch Intern Med 137: $507-513$

7. Cahill GH (1971) Physiology of insulin in man. Diabetes 20: 785-798

8. Lukens FDW (1953) The influence of insulin on protein metabolism. Diabetes 2: 491-497

9. Luck JM, Morrinson G, Wilbur LF (1929) The effect of insulin on the amino acid content of blood. J Biol Chem 77: 151-156
10. Felig P (1975) Amino acid metabolism in man. Ann Rev Biochem 44: 933-955

11. Pozefsky T, Felig P, Tobin JD (1969) Amino acid balance across tissues of the forearm in postabsorptive man. Effects of insulin at two dose levels. J Clin Invest 48: 2273-2282

12. Jefferson LS (1980) Role of insulin in the regulation of protein synthesis. Diabetes $29: 487-496$

13. Hay AM, Waterlow JC (1967) The effect of alloxan diabetes on muscie and liver protein synthesis in the rat, measured by constant infusion of L- $\left({ }^{14} \mathrm{C}\right)$ lysine. J Physiol 191: 111-112

14. Odera BR, Sreedevi SD, Millward DJ (1982) Muscle protein synthesis in the streptozotocin-diabetic rate: A possible role of corticosterone in the insensitivity to insulin infusions in vivo. Biochem J 202:363-368

15. Pain VM, Garlick PJ (1974) Effect of streptozotocin diabetes and insulin treatment on the rate of protein synthesis in tissues of the rat in vivo. J Biol Chem 249: 4510-4514

16. Garrow JS, Hawes SF (1972) The role of amino acid oxidation in causing 'specific dynamic action' in man. Br J Nutr 27:211-219

17. Adams RF (1974) Determination of amino acid profiles in biological samples by gas chromatography. J Chromatography 95: 189-212

18. Halliday D, Read WWC (1981) Mass spectrometric assay of stable isotopic enrichment for the estimation of protein turnover in man. Proc Nutr Soc 40: 321-334

19. Smith T, Hesp R, Mackenzie J (1979) Total body potassium calibrations for normal and obese subjects in two types of whole body counter. Phys Med Biol 24: 171-175

20. Heding LG (1975) Radioimmunological determination of human C-peptide in serum. Diabetologia 11: 541-548

21. Waterlow JC, Garlick PJ, Millward DJ (1978) (eds) General principles of the measurement of the whole body protein turnover. In: Protein turnover in mammalian tissues and in the whole body. North-Holland, Amsterdam New York Oxford, pp 225-249

22. Matthews DE, Motil KJ, Rohrbaugh DK, Burke JF, Young VR, Bier DM (1980) Measurement of leucine metabolism in man from a primed, continuous infusion of $\mathrm{L}-\left[1-{ }^{13} \mathrm{C}\right]$ leucine. Am J Physiol 238: E473-E497

23. Wahren J, Felig P, Caseri E, Luft R (1972) Splanchnic and peripheral glucose and amino acid metabolism in diabetes mellitus. $\mathrm{J}$ Clin Invest 51: 1870-1878

24. McNurlan MA, Garlick PJ (1981) Protein synthesis in liver and small intestine in protein deprivation and diabetes. Am J Physiol 241: E238-E245

25. Peavy DE, Hansen RJ (1976) Lack of effect of amino acid concentration on protein synthesis in the perfused rat liver. Biochem $J$ 160: 797-801

26. Buse MG, Reid SS (1975) Leucine: a possible regulator of protein turnover in muscle. J Clin Invest 58: 1251-1261

27. Mitch WE, Walser M, Sapir DG (1981) Nitrogen sparing induced by leucine compared with that induced by its keto analogue, $L$ ketosiscaproate, in fasting obese man. J Clin Invest 67: 553-562

28. Nair KS, Garrow JS, Halliday D, Mahler RF (1983) Energy expenditure in uncontrolled insulin-dependent diabetic patients. Clin Sci 64: 24P

29. Sener A, Somers G, Davies G, Malaisse WJ (1981) The stimulussecretion coupling of amino-acid induced insulin release. Biosynthetic and secretory responses of rat pancreatic islet to L-leucine and C-glutamine. Diabetologia 21: 135-142

30. Rennie MJ, Edwards RHT, Halliday D, Matthews DE, Wolman SL, Millward DJ (1982) Muscle protein synthesis measured by stable isotope techniques in man: the effects of feeding and fasting. Clin Sci 63: 517-519

Received: 11 February 1983

and in revised form: 30 June 1983

Dr. K.S. Nair

Division of Clinical Sciences

Clinical Research Centre

Harrow, Middlesex HA1 3UJ, UK 